\title{
Effect of rye level, fat source and enzyme supplementation on fat utilization, diet metabolizable energy, intestinal viscosity and performance of broiler chickens
}

\section{Stefania Smulikowska and Anna Mieczkowska}

\author{
The Kielanowski Institute of Animal Physiology and Nutrition, \\ Polish Academy of Sciences \\ 0.5-110 Jablonna, Poland
}

(Reccived 25 May 1996; accepted 13 September1996)

\begin{abstract}
Two experiments were conducted on 272 young broiler cockerels to determine the effect of rye level, degree of saturation of added fat and supplementation with enzyme preparations containing xylanase and $\beta$-glucanase on the nutritional value of rye-containing diets fortified with 8.5 (Experiment 1) or $6 \%$ (Experiment 2) fat.

In Experiment 1, increasing the rye level $(0,15,30$ and $45 \%)$ in the dict containing $11.5 \%$ crude mixed fat significantly depressed ( $P \leqslant 0.001)$ organic mattcr retention (OMR), protein (APD) and fat $(A F D)$ apparent digestibility. The metabolizable cnergy value $\left(A M E_{N}\right)$ of the $45 \%$ rye diet was $8.5 \%$ lower than predicted because of this depression. Supplementation of diets with an enzyme preparation significantly improved $\mathrm{OMR}, \mathrm{A} F \mathrm{D}, \mathrm{AME}_{\mathrm{N}}(\mathrm{P} \leqslant 0.001)$ and $\mathrm{APD}(\mathrm{P} \leqslant 0.01)$ in ryccontaining diets. The $\mathrm{AME}_{\mathrm{N}}$ of the supplemented diet containing $45 \%$ rye was $1.7 \%$ higher than predicted.

In Experiment 2, substitution of unsaturated (soya oil) with more saturated fats (lard or tallow, or soya oil and tallow 1:1) in the diet containing 30\% rye, caused a significant decrease in AFD $(P \leqslant 0.001)$, OMR and APD ( $\mathrm{P} \leqslant 0.05)$. The AME $\mathrm{A}_{\mathrm{N}}$ of the tallow-containing dict was $1.28 \mathrm{MJ} / \mathrm{kg}$ DM lower than of the soya vil-containing diet. Cockerels fed the tallow-containing diet were lighter and used $13 \%$ more feed per gram of body weight gain (BWG). The degree of saturation of added fat did not affect the viscosity of intestinal digesta, but the viscosity of droppings was signiticantiy higher in birds fed saturated fats.

Enzyme supplementation significantly reduced $(P \leqslant 0.001)$ both intestinal and excreta viscosity, OMR, AFD and $A M E_{N}$. Cockerels fed enzyme-supplemented diets were on average $10 \%$ heavier and
\end{abstract}

The research was financed by grant No 5. S 30505106 from the Commitlee for Scientific Research 
used $15 \%$ less feed per gram BWG. The greatest difference in the $\Lambda \mathrm{ME}_{\mathrm{N}}$ value $(1.65 \mathrm{MJ} / \mathrm{kg} \mathrm{DM})$ was noted between supplemented and unsupplemented tallow-containing diets.

The results of these experiments suggest that enzyme supplementation is necessary in particular if broiler diets contain both a high level of rye and saturated animal fat.

KEY WORDS: rye, fat, metabolizable energy value, chicks, enzyme supplementation

\section{INTRODUCTION}

Rye is one of the main cereals grown in Poland and, as its market price is usually much lower than the price of wheat, it can be considered an acceptable component of poultry rations. However, the use of rye as an alternative feedstuff in broiler diets is negligible. Many investigations have demonstrated that substitution of wheat by rye in broiler chicken diets results in depression of performance, wet and sticky droppings, and symptoms of rachitis (Antoniou and Marquardt, 1982; Campbell et al., 1983; Pettersson and Åman, 1988; Friesen et al., 1991; Bedford and Classen, 1992). These effects are related to the higher soluble non-starch polysaccharide (NSP) content in rye and its ability to form a viscous gel in the digestive tract of chickens (Antoniou et al., 1981; Bedford and Classen, 1992). There is ample evidence that the anti-nutritive effects of soluble NSP of wheat and rye can be reduced by the use of feed enzymes (Fengler et al., 1988; Pettersson and Åman, 1988; 1989; Groot Wassink et al., 1989; Pawlik et al., 1990; Friesen et al., 1991; Pettersson et al., 1991; Marquardt et al., 1994; Annison, 1995; Dänicke et al., 1995; Smulikowska, 1995). However, little information is available about dietary factors that can influence the magnitude of the effect of enzyme preparations.

The metabolizable energy value $\left(\mathrm{AME}_{\kappa}\right)$ of rye according to the European Table of Energy Values for Poultry Feedstuffs (1989) is low, and considerable amounts of fat should be added to rye-containing broiler diets to adjust their energy content to the requirement of broiler chickens. Substitution of wheat by rye in broiler chicken dicts has been reported to decrease nutrient digestibility and absorption in general (Friesen et al., 1992), fat in particular (Antoniou and Marquardt, 1981,1982). Addition of xylanases to wheat- and rye-based diets improved the digestibility of nutrients, particularly fat (Fengler at al., 1988; Pettersson and Åman, 1989). Schutte et al. (1995) and Dänicke et al. (1995) showed that this effect was more pronounced when diets contained saturated animal fat.

The aim of the current experiments was to evaluate the effect of rye level, enzyme supplementation and degree of saturation of added fat on protein and fat digestibility, the metabolizable energy value of diets and performance of broiler chickens. 


\section{MATERIAL AND METHODS}

Two experiments were conducted on 272 broiler cockerels of Starbro strain, purchased from a commercial hatchery and reared on broiler starter diet until the experiments started. Prior to the beginning of each experiment the birds were starved for $4 \mathrm{~h}$, weighed and all very small and very large birds rejected. Birds selected for experiments were allocated randomly to experimental groups according to weight, placed in balance cages equipped with feed and water supply and fed cold pelleted diets to appetite for 1 (Experiment 1) or 2 (Expcriment 2) weeks. Balance studies were carried out when the chicks were 28 (Experiment 1 ) or 21 (Experiment 2) days old. The amount of food consumed over a 3-day period was recorded, voided excreta were collected daily and kept frozen at $-18^{\circ} \mathrm{C}$ until analyzed. In both experiments, $0.3 \% \mathrm{Cr}_{2} \mathrm{O}_{3}$ was added as a marker to the diets used in the balance studics.

Experiment I was performed on 80 three-week-old cockerels with an average initial weight of $67 \mathrm{l} \pm 5 \mathrm{~g}$, divided into 8 groups of ten birds. The cockerels were housed individually and fed diets based on wheat var. Sigma and rye var. Motto fortified with $85 \mathrm{~g}$ of mixed fat per $\mathrm{kg}$ of diet. Wheat was the only cereal in the control diet; in the experimental diets, 150,300 or $450 \mathrm{~g}$ of wheat per kilogram of diet were substituted by rye. Each diet was fed either non-supplemented or supplemented with $1.5 \mathrm{~g} / \mathrm{kg}$ of Avizyme Tx enzyme preparation containing 400 units of xylanase, 150 units of $\beta$-glucanase and 500 units of protease per gram, according to the manufacturer's specification (Finnfeeds Int.). The composition of the experimental diets is given in Table 1. All diets contained an antibiotic (flavophospholopol, $5 \mathrm{mg} / \mathrm{kg}$ diet).

Experiment 2 was performed on 192 two-week-old cockerels with an average initial weight of $288 \pm 5 \mathrm{~g}$, divided into 8 groups. The birds were housed in pairs, 12 pairs constituted an experimental group. The cockerels were fed diets based on rye and wheat mixed in about equal proportions and fortified with $60 \mathrm{~g} / \mathrm{kg}$ of added fat (Table 1). The diets differed only in fat source: soya oil, lard, beef tallow or soya oil and beef tallow mixed 1:1. All diets contained an antibiotic (flavophospholipol, $5 \mathrm{mg} / \mathrm{kg}$ diet). Each of the fat basal diets was tested with or without $0.75 \mathrm{~g} / \mathrm{kg}$ of an enzyme preparation, Endofeed, containing 2250 units of pentosanase and 1000 units of $\beta$-glucanase per gram, according to the producer's specification (GNC Bioferm Inc.). The composition of the experimental diets is given in Table 1.

Weight gain of cockerels and feed consumption were recorded weekly after a $4 \mathrm{~h}$ fast. During the first week of the experiment the dry matter content and viscosity of fresh excreta samples were measured. At the end of the experiment the chicks were killed by decapitation and dissected. The ileum and jejunum were ligated, excised, and their content removed. Intestinal content from 2 chicks was 
TABLE 1

Composition of experimental diets, $\mathrm{g} / \mathrm{kg}$ diet

\begin{tabular}{|c|c|c|c|c|c|}
\hline \multirow{2}{*}{ Component } & \multicolumn{4}{|c|}{ Experiment 1} & \multirow{2}{*}{ Experiment 2} \\
\hline & 1 and $1 \mathrm{E}$ & 2 and $2 E$ & 3 and $3 \mathrm{E}$ & 4 and $4 \mathrm{E}$ & \\
\hline Rye var. Motto & - & 150 & 300 & 450 & 300 \\
\hline Wheat var. Sigma & 590.5 & 439.5 & 288.5 & 137.5 & 292.25 \\
\hline Soyabean meal & 260 & 260 & 260 & 260 & 281 \\
\hline Fish $^{f}$ or meat ${ }^{\text {th }}$ meal & $30^{\mathrm{f}}$ & $30^{f}$ & $30^{:}$ & $30^{\mathrm{r}}$ & $30^{\mathrm{m}}$ \\
\hline Fat $^{1}$ & 85 & 85 & 85 & 85 & 60 \\
\hline Mineral-vitamin premix ${ }^{\underline{y}}$ & 27 & 27 & 27 & 27 & 29 \\
\hline $\mathrm{NaCl}$ & 3 & 4 & 5 & 6 & 4 \\
\hline $\mathrm{Cr}_{2} \mathrm{O}_{3}$ & 3 & 3 & 3 & 3 & $3^{3}$ \\
\hline Enzyme $^{4}$ or starch & 1.5 & 1.5 & 1.5 & 1.5 & 0.75 \\
\hline \multicolumn{6}{|l|}{ Nutrient concentration } \\
\hline Crude protein, \% & 22.32 & 21.72 & 21.30 & 20.52 & 22.15 \\
\hline Crude fat, $\%$ & 11.70 & 11.56 & 11.36 & 11.28 & 8.23 \\
\hline
\end{tabular}

${ }^{1}$ Experiment 1 - soya oil mixed with lard in proportion 1:1; Experiment 2 - soya oil or lard or tallow or soya oil mixed with tallow in proportion 1:1

${ }^{2}$ supplied per kg of diet: limestone $10 \mathrm{~g}$; dicalcium phosphate $12 \mathrm{~g}$; vit. $\mathrm{A} 1200 \mathrm{IU}$; vit. $\mathrm{D}_{3} 2500 \mathrm{IU}$; vit. E $20 \mathrm{mg}$; vit. $\mathrm{K}_{3} 2 \mathrm{mg}$; vit. $\mathrm{B}_{1} 1,5 \mathrm{mg}$; vit. $\mathrm{B}_{2} 6 \mathrm{mg}$; vit. $\mathrm{B}_{6} 3 \mathrm{mg} ;$ vit. $\mathrm{B}_{12} 0.02 \mathrm{mg}$; nicotinic acid $20 \mathrm{mg}$; panthothenic acid $12 \mathrm{mg}$; folic acid $1 \mathrm{mg}$; biotine $0.1 \mathrm{mg}$; choline $300 \mathrm{mg}$; Mn $70 \mathrm{mg}$; Zn $60 \mathrm{mg}$; Fe 30 $\mathrm{mg}$; $\mathrm{Cu} 7.5 \mathrm{mg}$; J $0.5 \mathrm{mg}$; Se $0.2 \mathrm{mg}$; Co $0.3 \mathrm{mg}$; diclazuril $1 \mathrm{mg}$; flavophospholipol $5 \mathrm{mg}$; in Experiment 2 also DL-methionine $\mathrm{Ig}$ and L-lysine $\mathrm{lg}$

${ }^{3}$ in Experiment $2 \mathrm{Cr}_{2} \mathrm{O}_{3}$ was added only during the balance period

${ }^{4}$ in Experiment 1 Avizyme Tx (Finnfeeds Int.); in Experiment 2 Endofecd (GNC Bioferm Inc.)

pooled, mixed and centrifuged at $10000 \mathrm{x} \mathrm{g}$ for $10 \mathrm{~min}$. The viscosity of the supernatant was immediately measured on a Brookfield digital viscometer, model DV-II + I.V at $40^{\circ} \mathrm{C}$.

Excreta collected during balance periods in both experiments were homogenized, dried in a force-draft drying oven at $80^{\circ} \mathrm{C}$, finely ground in a laboratory mill, mixed thoroughly and kept in screw-cap bottles until analyzed. Dry matter, crude protein ( $\mathrm{N} \times 6.25)$, crude ash were determined in samples of diets and excreta by standard methods, crude fat by ethyl ether extraction without acid hydrolysis, faecal $\mathrm{N}$ in excreta according to Ekman et al. (1949), gross energy by Parr adiabatic oxygen bomb calorimeter, chromic oxide was determined spectrophotometrically following wet ashing according to the procedure described by Hinsberg et al. (1953).

Crude fat retention values were reported as fat digestibilities, as avian urine has a very low lipid content which is independent of the dietary concentration of lipids (Sell and McKirdy, 1963). Apparent metabolizable energy $\left(\mathrm{AME}_{\mathrm{N}}\right)$ of the 
diets was calculated relative to the ratio of $\mathrm{Cr}_{2} \mathrm{O}_{3}$ to gross energy in food and droppings and corrected to zero nitrogen balance using $1.96 \mathrm{MJ} / \mathrm{g}$ nitrogen retained (Hill and Anderson, 1958).

Data were subjected to two-way analysis of variance using the Statgraphics Plus ver. 7 Software.

\section{RESULTS}

Substitution of increasing amounts of rye or wheat in diets fortified with mixed fat but unsupplemented with enzyme significantly decreased dietary organic matter (OMR) retention ( $\mathrm{P} \leqslant 0.001 ; \mathrm{r}=-0.98)$, apparent protein (APD) digestibility $(\mathrm{P} \leqslant 0.001 ; \mathrm{r}=-0.99)$, apparent fat (AFD) digestibility $(\mathrm{P} \leqslant 0.001$; $r=-0.96)$ and metabolizable energy value $\left(\mathrm{AME}_{\mathrm{Nc}}\right)$ of diets (Experiment 1 , Table 2). Birds fed unsupplemented $45 \%$ rye diet excreted $25.3 \%$ of the dietary fat undigested, in comparison with $8.5 \%$ excreted by birds fed the control wheat diet. Supplementation of the diets with an enzyme preparation had a marked positive effect on OMR $(\mathbf{P} \leqslant 0.001)$, APD $(P \leqslant 0.01)$ and AFD $(P \leqslant 0.001)$, however, OMR and fat digestibility in the chicks fed the enzyme-supplemented $45 \%$ rye diet were significantly lower than in chicks fed the control wheat diet. A significant fat $x$ enzyme interaction was observed for OMR, $A F D$ and $A M E_{N}$. Supplementation with the enzyme did not affect nutrient utilization of the control wheat diet, and its effect was more pronounced in the diets containing high rye levels.

The results of Experiment 2 are shown in Tables 3 and 4. Birds fed the diet containing $30 \%$ rye and $6 \%$ added tallow grew more slowly, however, statistical analysis failed to show a significant difference at $\mathbf{P}=0.05$ due to large between-bird variation. Type of fat did not significantly affect the weight of the liver, but significantly $(\mathrm{P} \leqslant 0.001)$ negatively affected the feed conversion ratio (FCR), which was $13 \%$ higher on tallow-containing diets than on soya oil-containing diets. There was no interaction between the effect of fat source and enzyme supplementation on BWG and FCR. The fat source did not affect the DM of excreta, but significantly affected the viscosity of excreta $(P \leqslant 0.001)$ and digesta $(\mathrm{P} \leqslant 0.05)$.

The fat source did not affect APD significantly, but its effect on fat digestion was highly significant $(\mathrm{P} \leqslant 0.001)$. As much as $54.5 \%$ of dietary lipids were undigested and excreted on the unsupplemented tallow-containing diet in comparison with only $24.1 \%$ on the unsupplemented soya oil-containing diet. This was reflected in significantly lower OMR, metabolizability of energy and $\mathrm{AME}_{\mathrm{N}}$ of the tallow-containing diet. 


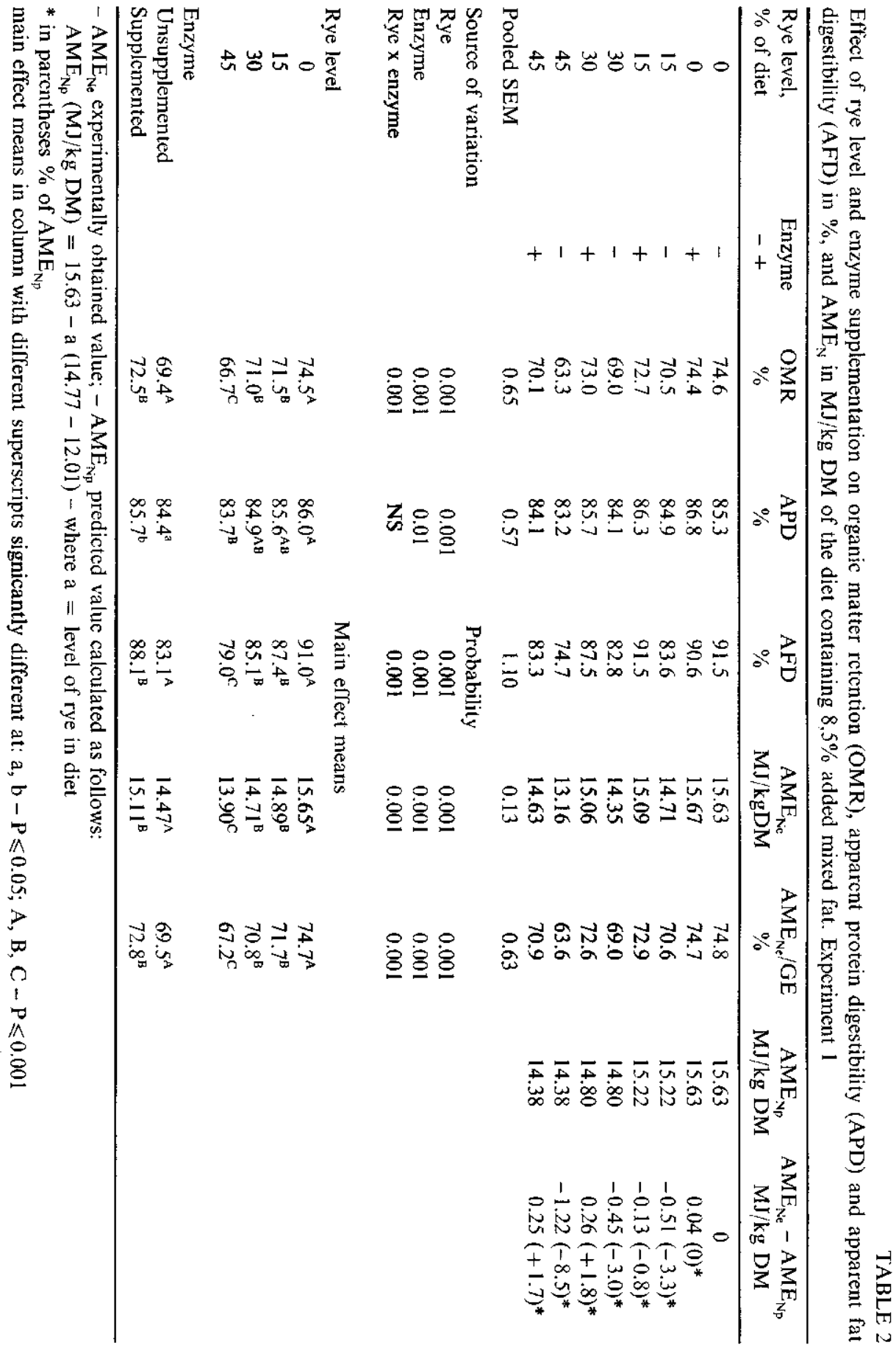


TABLE 3

Body weight gain (BWG) in g, feed conversion ratio ( $\mathrm{g}$ feed/g BWG), weight of liver ( $\%$ of BW), DM of excreta (\%), viscosity of excreta and digesta (cP). Experiment 2

\begin{tabular}{|c|c|c|c|c|c|c|c|}
\hline \multicolumn{2}{|c|}{ Dietary treatment } & \multirow{2}{*}{$\begin{array}{c}\text { BWG, } \\
\mathrm{g}\end{array}$} & \multirow{2}{*}{$\begin{array}{c}\text { FCR, } \\
\mathrm{g} / \mathrm{g}\end{array}$} & \multirow{2}{*}{$\begin{array}{l}\text { Liver, } \\
\% \text { BW }\end{array}$} & \multirow{2}{*}{$\begin{array}{l}\text { Excreta } \\
\text { DM, \% }\end{array}$} & \multicolumn{2}{|c|}{ Viscosity, cP } \\
\hline Fat source & $\begin{array}{c}\text { Enzyme } \\
-+\end{array}$ & & & & & cxcreta & digesta \\
\hline Soya oil & - & 730 & 2.06 & 2.64 & 26.4 & 50.3 & 49.8 \\
\hline Lard & - & 690 & 2.07 & 2.67 & 26.8 & 130.4 & 46.2 \\
\hline Tallow & - & 681 & 2.33 & 2.83 & 27.4 & 287.7 & 30.7 \\
\hline Mixed fat ${ }^{1}$ & - & 712 & 2.12 & 2.70 & 26.2 & 92.6 & 41.2 \\
\hline Soya oil & + & 783 & $1: 76$ & 2.72 & 28.2 & 29.0 & 16.5 \\
\hline Lard & + & 804 & 1.83 & 2.71 & 27.8 & 30.8 & 17.9 \\
\hline Tallow & + & 777 & 1.93 & 2.80 & 26.8 & 27.4 & 20.5 \\
\hline Mixed fat ${ }^{i}$ & + & 765 & 1.81 & 2.62 & 29.3 & 23.1 & 16.4 \\
\hline Pooled SEM & & 18 & 0.05 & 0.18 & 0.48 & 27.7 & 2.7 \\
\hline Source of variation & \multicolumn{7}{|c|}{ Probability } \\
\hline Fat & & NS & 0.001 & NS & NS & 0.001 & NS \\
\hline Enzyme & & 0.001 & 0.001 & NS & 0.001 & 0.001 & 0.001 \\
\hline Fat $x$ enzyme & & NS & NS & $\dot{N} S$ & 0.05 & 0.01 & 0.001 \\
\hline \multicolumn{8}{|c|}{ Main effect means } \\
\hline \multicolumn{8}{|l|}{ Fat source } \\
\hline Soya oil & & 755 & $1.91^{\mathrm{A}}$ & 2.68 & 27.3 & $40.8^{\mathrm{A}}$ & 30.8 \\
\hline Lard & . & 748 & $1.95^{\wedge}$ & 2.69 & 27.3 & $86.1^{\mathrm{A}}$ & 31.1 \\
\hline Tallow & & 726 & $2.15^{\mathrm{B}}$ & 2.82 & 27.1 & $172.0^{\mathrm{B}}$ & 25.6 \\
\hline Mixed fat ${ }^{\prime}$ & & 734 & $1.98^{\wedge}$ & 2.66 & 27.7 & $61.7^{\wedge}$ & 28.8 \\
\hline \multicolumn{8}{|l|}{ Enzyme } \\
\hline Unsupplemented & & $703^{\mathrm{A}}$ & $2.15^{\mathrm{A}}$ & 2.72 & $26.7^{\wedge}$ & $140.3^{\wedge}$ & $41.3^{\wedge}$ \\
\hline Supplemented & & $783^{B}$ & $1.83^{\mathrm{B}}$ & 2.71 & $28.0^{\mathrm{B}}$ & $27.6^{\mathrm{B}}$ & $17.8^{\mathrm{B}}$ \\
\hline
\end{tabular}

' soya oil and tallow in proportion 1:1

main effect means in column with different superscripts signicantiy different $a t: a, b-P \leqslant 0.05$; A, B $-P \leqslant 0.001$

Enzyme supplementation resulted in a significant increase of BWG $(P \leqslant 0.001)$, decrease of FCR $(P \leqslant 0.001)$, increased DM of excreta $(P \leqslant 0.001)$ and decreased $(P \leqslant 0.001)$ viscosity of excreta and digesta $(P \leqslant 0.01) . A$ highly significant $(P \leqslant 0.001)$ increase in OMR, AFD and $A P D, A M E_{N}$ values and metabolizability of energy had been noted for all basal diets. It should be stressed that the reaction of individual birds to tallow in the diet was variable, the highest variation in all of the measured and calculated parameters was observed in the group fed the tallow-containing diet. Supplementation with the enzyme preparation reduced the between-bird variation in the tallow-fed group, as well as in the remaining groups.

A significant fat $x$ enzyme interaction was observed on $D M(P \leqslant 0.05)$ of excreta (enzyme supplementation lowered the DM of droppings in birds fed the 
TABLE 4

Effect of fat source and enzyme supplementation on organic matter retention (OMR), apparent protcin digestibility (APD), and apparent fat (AFD) digestibility (in \%), and on $A M E_{N}$ value $(M J / k g$ $\mathrm{DM}$ ) of the diets containing $30 \%$ of rye and $6 \%$ of added fat. Experiment 2

\begin{tabular}{|c|c|c|c|c|c|c|}
\hline \multicolumn{2}{|c|}{ Dictary treatment } & \multirow{2}{*}{$\begin{array}{c}\text { OMR } \\
\%\end{array}$} & \multirow{2}{*}{$\begin{array}{c}\text { APD } \\
\%\end{array}$} & \multirow{2}{*}{$\begin{array}{c}\text { AFD } \\
\%\end{array}$} & \multirow{2}{*}{$\begin{array}{c}\Lambda \mathrm{ME}_{\mathrm{N}} \\
\mathrm{MJ} / \mathrm{kg} \mathrm{DM}\end{array}$} & \multirow{2}{*}{$\underset{\%}{\mathrm{AME}_{\mathrm{N}} / \mathrm{GE}}$} \\
\hline Fat source & $\begin{array}{c}\text { Enzyme } \\
-+\end{array}$ & & & & & \\
\hline Soya oil & - & 64.5 & 83.8 & 75.9 & 13.53 & 64.9 \\
\hline Lard & - & 66.4 & 85.6 & 66.4 & 12.86 & 64.0 \\
\hline Tallow & - & 60.0 & 85.2 & 45.5 & 12.25 & 58.8 \\
\hline Mixed fat ${ }^{\prime}$ & - & 64.6 & 86.3 & 61.7 & 13.02 & 64.3 \\
\hline Soya oil & + & 71.6 & 85.7 & 84.8 & 14.69 & 71.3 \\
\hline Lard & + & 69.7 & 85.7 & 77.7 & 13.80 & 68.3 \\
\hline Tallow & + & 69.2 & 86.1 & 63.1 & 13.90 & 67.6 \\
\hline Mixed fat ${ }^{\prime}$ & + & 71.4 & 86.5 & 73.9 & 14.76 & 70.6 \\
\hline Pooled SEM & & 1.08 & 0.39 & 1.82 & 0.20 & 0.99 \\
\hline \multicolumn{3}{|l|}{ Source of variation } & \multicolumn{3}{|c|}{ Probability } & \\
\hline Fat & & 0.003 & 0.003 & 0.001 & 0.001 & 0.001 \\
\hline Enzyme & & 0.001 & NS & 0.001 & 0.001 & 0.001 \\
\hline \multicolumn{2}{|l|}{ Fat $x$ enzyme } & NS & NS & NS & NS & NS \\
\hline & & \multicolumn{4}{|c|}{ Main effect means } & \\
\hline \multicolumn{7}{|l|}{ Fat source } \\
\hline Soya oil & & $68.3^{a}$ & $84.8^{:}$ & $80.6^{\mathrm{A}}$ & $14.14^{\mathrm{A}}$ & $68.3^{\mathrm{A}}$ \\
\hline Lard & & $68.1^{a}$ & $85.7^{\mathrm{ah}}$ & $72.3^{\mathrm{B}}$ & $13.36^{\mathrm{BC}}$ & $66.3^{\mathrm{AB}}$ \\
\hline Tallow & & $64.4^{b}$ & $85.8^{\mathrm{ab}}$ & $54.2^{\mathrm{C}}$ & $13.03^{\mathrm{C}}$ & $63.0^{\mathrm{B}}$ \\
\hline Mixed fat ${ }^{\prime}$ & & $67.8^{\mathrm{a}}$ & $86.4^{\mathrm{b}}$ & $67.4^{\mathrm{B}}$ & $13.84^{\mathrm{AB}}$ & $67.3^{\mathrm{A}}$ \\
\hline \multicolumn{7}{|l|}{ Enzyme } \\
\hline Unsupplemented & & $63.7^{\mathrm{A}}$ & $85.4^{a}$ & $61.7^{\lambda}$ & $12.88^{\mathrm{A}}$ & $62.9^{\mathrm{A}}$ \\
\hline Supplemented & & $70.4^{\mathrm{B}}$ & $86.0^{\mathrm{a}}$ & $74.9^{\mathrm{B}}$ & $14.27^{\mathrm{B}}$ & $69.4^{\mathrm{B}}$ \\
\hline
\end{tabular}

'soya oil and taliow in proportion 1:1

main effect means in column with different superscripts signicantly different $a t: a, b-P \leqslant 0.05$; A, B, C $-\mathbf{P} \leqslant 0.001$

tallow-containing diet, increased the DM of droppings in the remaining groups), on viscosity $(P \leqslant 0.05)$ of excreta (the effect was more evident on the tallow- and lard-containing diets) and on viscosity $(P \leqslant 0.05)$ of digesta (the effect was numerically lower on the tallow-containing diet). No significant fat $\mathrm{x}$ enzyme interaction was noted on OMR, APD and AFD or on the AME ${ }_{\mathrm{N}}$ value of diets.

\section{DISCUSSION}

The metabolizable energy value of rye is lower $(12.00 \mathrm{MJ} / \mathrm{kg} \mathrm{DM})$ than of wheat (14.75 MJ $/ \mathrm{kg} \mathrm{DM}$ ), according to the European Table of Energy Values of 
Poultry Feedstuffs (1989). When wheat is substituted by rye, considerable amounts of fat should be added to adjust the energy content of the diet to the requirement of broiler chickens. However, the results of Experiment 1 (Table 2) show that such a strategy may not be satisfactory, even if the cost of rye and fat would be beneficial, because the efficiency of fat utilization in rye-containing diets is considerably lower. The metabolizable energy value $\left(\mathrm{AME}_{\mathrm{Ne}}\right)$ of an unsupplemented diet containing $11.5 \%$ mixed fat $(8.5 \%$ added $)$ decreased substantially as the rye level increased (Table 2). The $\mathrm{AME}_{\mathrm{N}}$ of the unsupplemented $45 \%$ rye-containing diet was $16 \%$ lower than of the unsupplemented wheat diet. This is close to the results presented by Friesen et al. (1991) who showed that substitution of $40 \%$ wheat by rye reduced the $\mathrm{AME}_{\mathrm{N}}$ of the diet by as much as $14.7 ; 50 \%$ rye inclusion by as much as $16.7 \%$.

In the present experiment the $\mathrm{AME}_{\mathrm{N}}$ values of unsupplemented ryecontaining diets were lower than predicted (calculated according to the $A M E_{N}$ values of wheat and rye taken from the European Table of Energy Values of Poultry Feedstuffs, 1989). The gap between metabolizable energy predicted and determined experimentally $\left(\mathrm{AME}_{\mathrm{Np}}-\mathrm{AME}_{\mathrm{N}_{\mathrm{c}}}\right)$ widened as the rye level increased; however, when the rye diets were supplemented with an enzyme preparation containing xylanase and $\beta$-glucanase, the $\mathrm{AME}_{\mathrm{N}}$ of the diets increased and the determined $A M E_{\mathrm{Ne}}$ values were higher than $A M E_{\wedge p}$ (Table 2).

The reduction in $\mathrm{AME}_{\mathrm{V}}$ of diets and poorer performance of chickens accompanying increased dietary inclusion of rye has been reported previously, as have the benefits of adding xylanase to rye-based diets (Campbell et al., 1983; Pettersson and Åman, 1988; 1989; Groot Wassink et al., 1989; Pettersson et al., 1991; Friesen et al., 1991,1992).

There is a considerable body of evidence that non-starch polysaccharides (NSP) present in rye and wheat may impair the digestion of nutrients (Antoniou et al., 1981; Fengler et al., 1988; Choct and Annison, 1992; Friesen et al., 1992). The chemical structure of NSP of wheat and rye is partly similar (Fincher and Stone, 1986), however, their physical properties are quite different, the most pronounced concern gel-forming property and water holding capacity, which are higher in rye. Most of the antinutritive activities of NSP, which directly affect bird performance, have been ascribed to viscosity created in the digestive tract by the soluble NSP fraction (Ward and Marquardt, 1983; Pawlik et al., 1990; Pettersson et al., 1991; Bedford and Classen, 1992).

The viscosity of digesta depends on the molecule size and structure of ingested soluble NSP, as well as on their concentration (Bedford and Classen, 1992; Annison,1995). The exact mechanism of the antinutritive activity of NSP is still not well understood. It is suggested that high viscosity slows passage, makes proper reflux and mixing of digesta more difficult, slows the rate of diffusion of feed substrates, digestive enzymes and their products and reduces transport of 
nutrients to the mucosal surface. Molecules of NSP in solution can present charged, weakly hydrophobic and weakly hydrophilic surfaces. They may associate with surfaces of food particles, lipid micelles or the glycocalyx surface of the gut (Johnson, 1992; Annison, 1995).Viscous polysaccharides might also complex directly with digestive enzymes and reduce their activity (Ikeda and Kusano, 1983).

In the present study, increasing the rye content of diets caused a significant decrease in the digestion of protein and a highly significant decrease in the digestion of fat (Table 2). It seems that high digesta viscosity affects the complex process of fat digestion in particular. Ingested fats should first be emulsified in the presence of conjugated bile salts and then subjected to the hydrolytic action of pancreatic lipase in the presence of colipase and pancreatic phospholipase A. The products of lipolysis - unsaturated long chain fatty acids, medium chain free fatty acids, monoglycerides and phospholipids form mixed micelles with conjugated bile salts. The hydrophobic cores of these mixed micelles have the ability to solubilize the long chain saturated fatty acids, diglycerides, fat soluble vitamins and cholesteryl esters. Micelles are transported to the mucosal surface and pass through the brush border membrane, leaving bile salts in the gut lumen. The main site of lipid absorption in fowls is the duodenum and jejunum, bile salts are absorbed in the jejunum and ileum (Scott at al., 1982; Annison, 1983; Krogdahl, 1985; Johnson, 1992).

As the rye content in the diet increased, the soluble, viscous NSP content in the digesta also increased, as did the flow of undigested organic matter to the ileum, which in turn may cause proliferation of detrimental microflora, able to deconjugate bile acids (Annison, 1995). Binding of bile acids by gel-forming soluble dietary fibres, as well as excessive bacterial bile acid deconjugation, may lead in turn to poor fat solubilization, as free bile acids are not active in a micelle formation (Campbell et al.,1983; Nagengast,1992).

Enzyme preparations containing xylanase and $\beta$-glucanase, which were specifically targeted against cell-wall non-starch polysaccharides (NSP), improved the fat and (to a lesser extent) protein digestibility, retention of organic matter and metabolizability of energy of the rye-containing diets (Table 2). The difference between metabolizable energy predicted and obtained experimentally $\left(\mathrm{AME}_{\mathrm{Np}}-\mathrm{AME}_{\mathrm{Ne}}\right.$ ) diminished (Table 2). In a previous experiment (Smulikows$\mathrm{ka}, 1995)$ a $9 \%$ increase in $\Lambda \mathrm{ME}_{\mathrm{N}}$ value of a rye diet due to enzyme supplementation was accompanied by a $4 \%$ increase in protein digestibility and $26 \%$ increase in fat digestibility. Also in Pettersson and Åman's (1989) study, an $8 \%$ increase of the $\mathrm{AME}_{\mathrm{V}}$ value of a wheat-rye diet due to enzyme supplementation was accompanied by a $6 \%$ increase in protein digestibility and $29 \%$ increase in fat digestibility. Annison (1995) concluded that improvement in the AME of cereal diets due to enzyme addition should be ascribed to improvement 
in nutrient (starch, protein, fats) digestibility and retention but not due to NSP itself becoming available to the chicken as a substantial energy source.

The excretion of watery and sticky droppings, observed when rye diets are fed, results in increased litter moisture (Marquardt et al., 1994) and creates management problems and additional hazards for birds. The supplementation of rye-based diets with an enzyme containing xylanase and $\beta$-glucanase was reported to reduce the occurrence of sticky droppings (Pettersson and $\AA$ man, 1989; Pettersson et al., 1991) and water content in excreta (Marquardt et al., 1994). The results of this study demonstrate (Table 3 ) that the amount of water in excreta diminished significantly after enzyme supplementation, but was not affected by the fat source in the diet.

The viscosity of excreta of birds fed unsupplemented diets depends, however, on the degree of saturation of the added fat, droppings of birds fed the mixed fat-, lard-, or tallow-containing diets were 80,160 and $470 \%$ more viscous than of birds fed the soya oil-containing diet. The presence of substantial amounts of undigested saturated fats, connected with viscous NSP may delay the movement of digesta. Under these conditions, more insoluble NSP may became solubilized in the last parts of the digestive tract due to the action of bacterial enzymes, adding to the viscosity and stickiness of excreta. Dänicke et al., (1995) reported that in 28-day-old birds fed rye and tallow-containing unsupplemented diets, viscosity in the jejunum was $100 \%$ higher, and in the ileum $240 \%$ higher than on rye and soya oil-containing diets. In the present study, the viscosity of digesta and excreta after enzyme supplementation diminished significantly and did not depend on the source of added fat (Table 3). Also Dänicke et al. (1995) showed that after enzyme supplementation the source of fat in a rye-containing diet had no effect on viscosity of digesta.

It was proved that both viscosity of excreta as well as presence of substantial amounts of undigested fat, which have an adverse effect on litter conditions, may increase the frequency of breast blisters and hock burns in broilers (Cooke and Raine, 1987). So enzyme supplementation, diminishing this adverse effect of dicts fortified with animal fat, may have additional beneficial effects on production.

The substitution of soya oil by lard, mixed fat or tallow in the unsupplemented diet did not affect protein digestibility, however, fat digestibility decreased by 10 , 14 and 30 percentage points, respectively. The supplementation of these diets with carbohydrases caused, on average, a $21 \%$ increase of AFD, the extent of improvement depends on degree of saturation of the added fat. Fat digestibility in birds fed enzyme supplemented diets containing soya oil increased by $12 \%$, in birds fed diets containing tallow by $39 \%$ in comparison to the unsupplemented dicts. The observed increase in AFD and OMR was correlated with better metabolizability of energy and a higher $\mathrm{AME}_{\mathrm{N}}$ value of the diets (Table 4). 
Tallow, due to the specific arrangement of saturated and unsaturated fatty acids on the glycerol moiety of the triglyceride molecule (a high proportion of palmitic and stearic acid is distributed throughout positions 1- and 3- of the triglyceride) is poorly digested and absorbed by poultry (Scott et al., 1982). Both palmitic and stearic fatty acids are nonpolar and cannot form mixed micelles spontaneously, but can be solubilized only by mixed micelles formed from unsaturated fatty acids and conjugated bile salts. Several investigators have reported that tallow is better absorbed in the presence of vegetable oil, which was confirmed in the present study. It also seems that the process of tallow digestion and absorption is particularly susceptible to the disturbances caused by the presence of viscous NSP in digesta.

Rye diets fortified with tallow have often been used to prove the beneficial effect of enzyme supplementation on the $\mathrm{AME}_{\mathrm{N}}$ value of rye-containing diets (Fengler and Marquardt, 1988; Friesen et al., 1992; Marquardt et al., 1994). It has been also demonstrated that the performance of rye-fed birds was better when the diet contained unsaturated fats as opposed to saturated fats (Antoniou and Marquardt, 1982; Ward and Marquardt, 1983). The results of this study, as well as findings of Dänicke et al. (1995) and Schutte et al. (1995), proved that degree of saturation of added fat plays a crucial role in the effective utilization of rye-based diets or poor quality wheat diets by broiler chickens. Partial solubilization of viscous NSP gels by added enzyme preparations, allowing better access of digestive enzymes to the substrates and undisturbed process of mixed micelle formation, may diminish the difference in utilization of diets containing unsaturated and saturated fats.

\section{CONCLUSIONS}

It may be concluded that both the rye level and the degree of saturation of added fat may greatly affect utilization of nutrients in rye-containing diets. Supplementation with an enzyme preparation containing xylanase and $\beta$-glucanase is particularly advisable if rye-containing diets are fortified with animal fat, since it may greatly enhance the retention of fat and organic matter and metabolizability of energy. This effect is associated with a reduction in the viscosity of digesta and excreta.

\section{ACKNOWLEDGMENTS}

The authors wish to thank Noack Polen Ltd. and Western Premix and Cons. for providing the enzyme preparations. 


\section{REFERENCES}

Annison E.F., 1983. Lipid metabolism. In: B.M. Freeman (Editor). Physiology and biochemistry of the domestic fowl. Academic Press, London, Vol. 4, pp. $165-174$

Annison G., 1995. Feed enzymes - the science, future developments and practical aspects in feed formulation. Proceedings of 10 th European Symposium on Poultry Nutrition, Antalya (Turkey), pp.193-201

Antoniou T.C., Marquardt R.R., Cansfield P.S., 1981. Isolation, partial characterisation and antinutritional activity of a factor (pentosans) in ryc grain. J. Agric. Food Chem. 29, 1240-1247

Antoniou T.C., Marquardt R.R., 1982. Utilization of rye diets by chicks as affected by lipid type and level and penicillin supplementation. Poultry Sci. 61, 107-116

Bedford M.R., Classen H.L., 1992. Reduction of intestinal viscosity through manipulation of dietary rye and pentosanase concentration is cffected through changes in the carbohydrate composition of the intestinal aqueous phase and results in improved growth rate and food conversion efficiency of broiler chicks. J. Nutr. 122, 560-569

Campbell G.L., Classen H.L., Goldsmith K.A., 1983. Effect of fat retention on the rachitogenic effect of rye fed to broilcr chicks. Poultry Sci. 62, 2218-2223

Choct M., Annison G., 1992.The inhibition of nutrient digestion by wheat pentosans. Brit. J. Nutr. 67, 123-132

Cooke B.C., Raine H.D., 1987. The application of nutritional principles by the commercial nutritionist. In: C. Fisher. K.N. Boorman (Editors). Nutrient requirements of poultry and nutritional research. Butterworths, London, pp. 191-200

Dänicke S., Simon O., Jeroch H., Bedford M., 1995. Effect of fat source and xylanase supplementation on the performance and intestinal viscosity in ryc fed birds. Proceedings of 2 nd European Symposium on Feed Enzymes, Noordwijkerhout (Netherlands), pp. 102-106

Ekman P., Fmanuelson H., Fransson A., 1949. The digestibility of protein in poultry. Kgl. Lantbruks-Hogskol. Ann. 16, 749

European Table of Energy Values for Poultry Fecdstuffs. 1989. Publ. Group No 2, Nutrition, European Federation WPSA, Bcckbergen, Netherlands

Fengicr A.I., Marquardi R.R., 1988. Water-soluble pentosans from rye: II. Effects on rate of dialysis and on the retention of nutrients by the chick. Cereal Chem. 65, 298-302

Fengler A.I., Pawlik J.R., Marquardt R.R., 1988. Improvement in nutrient retention and changes in excreta viscosities in chicks fed rye-containing diets suppiemented with fungal enzymes, sodium taurocholate and penicillin. Can. J. Anim. Sci. 68, 483-491

Fincher G.B., Stone B.A., 1986. Cell walls and their components in cereal grain technology. In: Y. Pomeranz (Editor). Advances in cereal science and technology. Minnesota AACC, Vol. 8, pp. 207-295

Friesen O.D., Guenter W., Marquardt R.R., Rotter B.A., 1992. The effect of enzyme supplementation on the apparent melabolizable energy and nutrient digestibilities of wheat, bariey, oats, and rye for the young broiler chick. Poultry Sci. 71, 1710-1721

Friesen O.D., Guenter W., Rotter B.A., Marquardt R.R., 1991. The effects of enzyme supplementation on the nutritive value of rye grain (Secale cereale) for the young broiler chick. Poultry Sci. $70,2501-2508$

GrootWassink J.W.D., Campbell G.L., Classen H.L., 1989. Fractionation of crude pentosanase (arabinoxylanase) for improvement of the nutritional value of rye diets for broiler chickens. $\mathbf{J}$. Sci. Food Agric. 46, 289-300

Hill F.W., Anderson D.L., 1958. Comparison of metabolizable encrgy and productive determinations with growing chicks. J. Nutr. 64, 587-603 
Hinsberg K., Cremer H.D., Schmid G., 1953. In: Hoppe-Seyler/Thierfelder- Handbuch der Physiologisch - und Patologisch - Chemischen Analyse. Springer-Verlag. 5, pp. 4(12-403

Ikeda K., Kusano T., 1983. In vitro inhibition of digestive enzymes by indigestible polysaccharides. Cereal Chem. 60, 260-263

Johnson I.T., 1992. The influence of dietary fibre on lipid digestion and absorption. In: T. F. Schweizer, C. Edwards (Editors). Dietary fibre - A Component of food - Nutritional function in health and discase. Springer-Verlag, London: ILSI Europc, pp. 167-180

Krogdahl A., 1985. Digestion and absorption of lipids in poultry. J. Nutr. 115, 675-685

Marquardt R.R., Boros D., Guenter W., Crow G., 1994. The nutritive value of barley, rye, wheat and corn for young chicks as affected by use of a Trichoderma reesei enzyme preparation. Anim. Feed Sci. Technol. 45, 363-378

Nagengast F.M., 1992. Dietary fibre and bile acid metabolism. In: T.F. Schweizer, C. Edwards (Editors). Dictary fibre $-\Lambda$ Component of food - Nutritional function in health and disease. Springer-Verlag London: ILSI Europe, pp. 217-231

Pawlik J.R., Fengler A.I., Marquardt R.R., 1990. Improvement of the nutritional value of rye by the partial hydrolysis of the viscous water-soluble pentosans following water-soaking or fungal cnzyme treatment. Brit. Poultry Sci. 31, 525-538

Pellersson D., Åman P., 1988. Fffects of enzyme supplementation of diets based on wheat, rye or triticale on their productive value for broiler chickens. Anim. Feed Sci. Technol. 20, 313-324

Pettersson D., Åman P., 1989. Enzyme supplementation of a poultry diet containing ryc and wheat. Brit. J. Nutr. 62, 139-149

Pettersson D., Graham II., Åman P., 1991. The nutritive value for broiler chickens of pelleting and enzyme supplementation of a diet containing barley, wheat and rye. Anim. Feed Sci. Technol. $33,1-14$

Schutte J.B., de Jong J., Langhout D.J., 1995. Effect of a xylanase enzyme suppiementation to wheat-based diets in broiler chicks in relation 10 dietary factors. Proceedings of 2 nd European Symposium on Feed Enzymes, Noordwijkerhout (Netherlands), pp. 95-101

Scott M.L., Nesheim M.C., Young R.J., 1982. Nutrition of the chicken. 3rd ed. Publ. by M. L. Scott and Ass. Ithaca, New York

Sell J.L.. McKirdy J.A., 1963. Lipids in chick urine: the influence of dictary rapesecd oil. Poultry Sci. 42, 380-383

Smulikowska S., 1995. Effect of enzymes on nutritional value of diets based on rye, wheat and triticale for broiler chicks. Proceedings of 2nd European Symposium on Feed Enzymes, Noordwijkerhout (Netherlands), p. 295

Ward A.T., Marquardt R.R., 1983. The effect of saturation, chain length of pure triglycerides, and age of bird on the utilization of rye diets. Poultry Sci. 62, 1054-1062

\section{S'TRESZCZENIE}

Wpływ żyta, rodzaju tłuszczu oraz uzupelniania enzymami na wykorzystanie składników pokarmowych i energię metaboliczną mieszanck, lepkość treści jelit oraz wyniki produkcyjne kurcząt brojlerów

Przeprowadzono 2 doświadczenia na 272 kogutkach brojlerach w celu zbadania wpływu poziomu żyta, rodzaju dodawanego tłuszczu oraz uzupelniania preparatami enzymatycznymi zawierającymi ksylanazęi $\beta$-glukanazę na wartość odżywczą mieszanck z udziałem żyta i dodatkiem $8,5 \%$ (Dośw. 1) lub 6\% (Dośw. 2) thušczu. 
W doświadczeniu 1 zwiększenie udzialu żyta w mieszance zawierającej $11,5 \%$ tłuszczu surowego spowodowało wysoce istotne $(P \leqslant 0,001)$ obniżenie pozornej strawności białka ogólnego (APD), tłuszczu surowego (AFD) i retencji masy organicznej (OMR) mieszanek. W następstwie tego wartość energii metabolicznej (AME N $_{\mathrm{N}}$ micszanki o zawartości $45 \%$ żyta była niźsza o $8,5 \%$ od obliczoncj. Uzupehnienie mieszanek preparatem enzymatycznym spowodowało wysoce istotne $(P \leqslant 0,001)$ zwiększenie pozornej strawności skladników mieszanek zawierających żyto. $\mathrm{AME}_{\mathrm{N}}$ mieszanki o zawartości $45 \%$ żyta była wyższa o $1,7 \%$ od obliczonej.

W doświadczeniu $2 \mathrm{w}$ mieszance zawierającej $30 \%$ żyta zastąpienie oleju sojowego tłuszczami o zwiększonym udziale nasyconych kwasów tłuszczowych (smalcem, micszaniną olcju sojowcgo i loju $1: 1$ lub łojem) spowodowało wysoce istotne $(P \leqslant 0,001)$ obniżenie $A F D$, istotne $(P \leqslant 0,05)$ obniżenie OMR i APD. AME $\mathrm{N}_{\mathrm{N}}$ miešanki zawierającej lój byla o $1,28 \mathrm{MJ} / \mathrm{kg}$ SM mniejsza od AME mieszanki $z$ olejem sojowym. Kurczęta otrzymujące mieszankę nathuszczaną tojem gorzcj rosły i zużyły o $13 \%$ więcej paszy na g przyrostu masy ciała. Stopień nasycenia dodawanego thuszczu nie miał wpływu na lepkość treści jelita cienkjego, leč istotnie zwiẹkszał lepkość odchodów.

Uzupełnienie mieszanek preparatem enzymatycznym spowodowało wysoce istotne $(P \leqslant 0,001)$ zmniejszenie lepkości treści jelita cienkiego i odchodów oraz zwiększenie pozornej strawności składników mieszanek i ich energii metabolicznej, co spowodowało, żc kurczęta przyrosły o $10 \%$ wiçccj i zıżyły o $15 \%$ mnicj paszy na g przyrostu niż kurczęta żywione mieszankami nieuzupełnionymi. Różnica między $\mathrm{AME}_{\mathrm{N}}$ mieszanki nieuzupełnionej i uzupełnionej enzymem była największa (1,65 MJ/ kg SM) przy nathuszczaniu łojem.

Wyniki obydwóch doświadczeń wskazują, że dodatek preparatów enzymatycznych jest niezbędny przy stosowaniu mieszanek zawierających dừ żyta, zwłaszcra gdy do natłuszczania stosuje się nasycone thuszcze zwierzęce. 